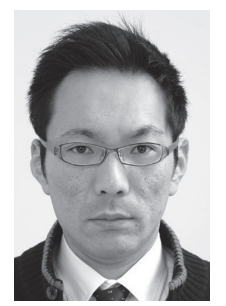

\title{
ナノ炭素材料の新展開
}

久 保 拓 也*

\section{New Evolution of Nano-Carbon Materials}

by

\author{
Takuya KuBo*
}

この度, ナノ材料部門委員会からの推薦を受け，本誌での 執筆の機会を頂きました。2012年から日本材料学会の会員と なり, 同時にナノ材料部門にも属し, 毎年春秋の講演会におい て発表の機会を頂いています.同部門内では, 無機・金属を中 心とした新規ナノ材料やその物性・機能評価が主として議論さ れる中, 新参者として, ナノ炭素材料を用いた新たな研究展開 について発表させていただいており，本項では，その一端につ いて, 紹介させていただきます.

私は, 2004 年に東北大学大学院環境科学研究科の助手に着 任して以来, 液相分離における新規分離場の構築に関して, 主 に有機多孔性材料を基材とした材料開発と機能性評価について 研究を進めてきました.この中には, マイクロメートルサイズ の三次元網目構造を持つモノリス材料や, 精密に制御された分 子認識材料の開発も含まれており, ナノテクノロジーの一つと して, 上記部門に精通する研究を展開してきました。一方で, 2010 年にJSPSの海外派遣事業の支援を受け，1年間米国にてナ ノ材料の固定化に寄与するインターフェイス開発に着手しまし た。同研究では, 種々の有機・無機ナノ粒子, ポリマー薄膜, 低分子の効率的な固定化法開発に成功し, さらに, グラフェン, カーボンナノチューブ, フラーレンなどのいわゆるナノ炭素材 料の固定化に非常に効果的であることも見いだしました。

ナノ炭素材料は, フラーレン, グラフェンの発見にノーベ ル賞が授与されたことからも明らかなように, 特異な物理化学 的性質を有する材料で, 特に強化材料や電子デバイスへの応用 が現在も活発に進められています.しかし，ナノ炭素材料をそ の特性を維持したまま効率的に固定化する技術は依然として開 発がそれほど進んでおらず, ナノ炭素材料の実用化には新たな 固定化法開発が求められています.

私は, これらの背景の基, 米国派遣から帰国後すぐに本来 の専門である液相分離媒体の開発に上述のナノ炭素材料固定化 技術を利用し，これまでに例のないナノ炭素材料を基材とする 分離場の構築に着手しました.本手法では, 特殊な光・熱活性 基である Perfluorophenyl azide (PFPA) と呼ばれる化合物を用い て， $\mathrm{C}_{60}$-フラーレンを固定化した分離場の構築を目指しました。 まず, 中空のフューズドシリカキャピラリーの内表面にC 60 を 固定化し, 低流量の送液が可能なマイクロ液体クロマトグラ フィー（マイクロLC）を用いてその分離能を評価しました。 その結果, 3 種の多環式芳香族炭化水素 $(\mathrm{PAH})$ の分離が 5 分以
内で達成されました。

さらに，分離能を向上させることを目的として，モノリス 材料の代表的な素材として知られる, シリカモノリスを用いて 同様の手法によってキャピラリーカラムを作製しました.図 1 に示すように，ミクロ孔とメソ孔を有するシリカモノリスに対 して， $\mathrm{C}_{60}$ とPFPAの誘導体を修飾することで， $\mathrm{C}_{60}$ 修飾型のシ リカモノリスキャピラリーの作製に成功しました。

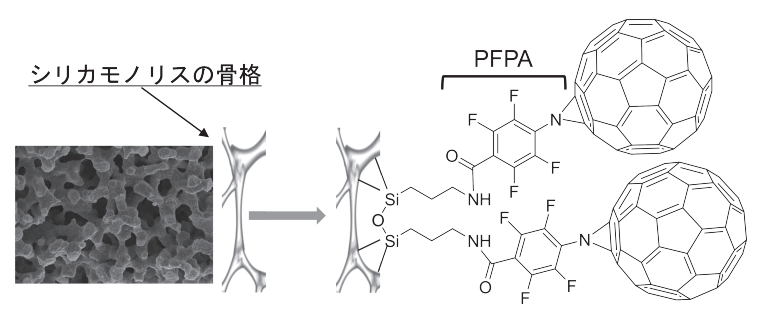

図 $1 \mathrm{C}_{60}$ 修飾型シリカモノリスのイメージ.

次に，得られた $\mathrm{C}_{60}$ 修飾型シリカモノリスキャピラリーを用 いて, 種々のPAHを溶質に用いたマイクロLC分析を行った結 果, 既存の分離カラムとは全く異なる保持選択性が確認され, $\mathrm{C}_{60}$ の $\pi$ 電子雲に基づく $\pi-\pi$ 相互作用が効果的に寄与する ことが明らかになりました.図2では, 移動相に非極性溶媒で ある $n$-hexaneを用いた場合のPAHおよび2臭素化ベンゼンの 分離例を示しましたが, 疎水的な相互作用が寄与しない系にお いても， $\pi-\pi$ 相互作用のみで分離が達成されていることが わかります。
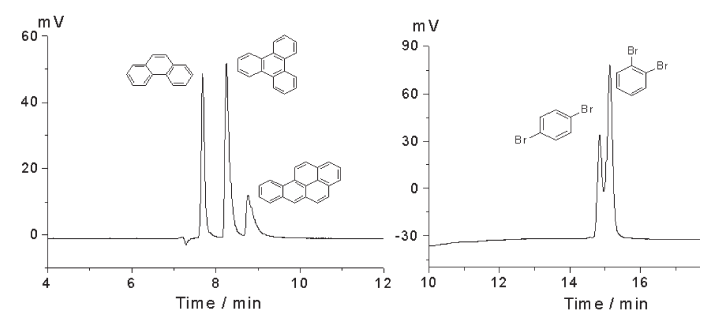

図 2 フラーレン修飾型シリカモノリスでの分離例.

以上のように, ナノ炭素材料の新展開として分離場として の有用性を紹介しましたが, 本技術は, 種々の材料へ適用可能 な固定化法であり，今後，ナノ金属材料等との複合体化によっ て, 新たな機能性材料の創成にも寄与できると期待しています.

$\dagger \quad$ 原稿受理 平成 27 年 2 月 6 日 $\quad$ Received Feb. 6, 2015 C2015 The Society of Materials Science, Japan

* 正 会 員 京都大学大学院工学研究科＝615-8510 京都市西京区京都大学桂, Graduate School of Eng., Kyoto Univ., Nishikyo-ku, Kyoto 615-8510 